\title{
Development and evaluation of a learning object focused on factors that might interfere on the radiographic image
}

\author{
Mísia Radesca Álvares Imgärtchen*; Renata Graziotin-Soares**; Diego Machado Ardenghi***; Vania \\ Regina Camargo Fontanella****
}

\author{
MSc in Dentistry, ULBRA Canoas \\ ** Assistant Professor, Department of Conservative Dentistry/ \\ Endodontics, UFRGS \\ *** Assistant Professor, University of Saskatchewan, Saskatoon, \\ Canada \\ **** Associate Professor, Surgery and Orthopaedics Department/ \\ Radiology, UFRGS
}

Recebido em 09/08/2016. Aprovado em 10/12/2016.

\begin{abstract}
Considering the difficulties to obtain good quality dental radiographic images taken by dental students, this study aimed to develop and to evaluate a Learning Object (LO), where the student is able to use a computer to simulate radiograph expositions, modifying the factors that interfere with the radiographic image quality. This study was exploratory and descriptive. For that, 48 periapical radiographs were obtained from the posterior region of a dried bone human jaw with different combinations of $\mathrm{kVp} / \mathrm{mA}$, film speed, focal distance, and time of exposition. Each radiograph received a "label" according to the factors used and also with a comment making a value judgment regarding its quality, its applicability for the diagnosis, and, if necessary, suggestions or questions about the required adjustments. In the LO screen students could simulate different situations (combination of factors) until obtaining the best result. Dental students ( $n=64)$ were divided into two groups. During the first week both groups participated in a theoretical lecture, and, subsequently, answered a test/assessment on the subject. In the following week Group 1 students solved practical exercises related to the subject, in the laboratory, and answered a second test/assessment. Students from Group 2 performed the activity with the LO in the laboratory. At the end of the activity, they also answered the test/assessment, and an open-ended questionnaire to evaluate the activity. At week3 the same activities from the week before were repeated, reversing the classes, and, then, a third test/assessment was applied. Statistical tests showed that there were no statistical differences in the groups' performance in any of the different moments of the evaluation. The use of the LO did not improved significantly the frequency of students' correctness (number of correct responses) in the tests/assessments. However, the LO methodology was considered very good, because, according to the participants, it was a tool that stimulates learning. The use of the LO, in addition to the practical exercises, contributed to the learning process on the factors that might interfere on the radiographic image.
\end{abstract}

Descriptors: Dental Education. Information and Communication Technologies. Learning Objects. Dental Radiology. 


\section{INTRODUCTION}

Education plays an important role in personal and professional development. For this, education may use technological resources as supporting tools for the teaching-learning process, as well as, facilitator methods/ methodologies in different stages during the professional training. These resources might help students to learn how to solve problems, independently. ${ }^{1}$

A Learning Object (LO) is one tool among the different possibilities to use Information and Communication Technologies (ICTs). LO is defined as any digital (or non-digital) resource based on technology, that can be used and reused during the learning process". 2,3 Currently, the definition of LO is still vague. ${ }^{4}$ However, several authors agree that the LO should have a definite educational aim and it should stimulate students' critical thinking. ${ }^{2,3,5,6}$

In Dental education, specifically in the contents of Dental Radiology, the topic "factors that interfere on the quality of radiographic images", requires that students understand abstract concepts. This understanding might be difficult because this complex subject is included at the beginning of the dental curriculum, and the students are in the initial phases of their dentistry program. Furthermore, there are several factors that can interfere with the result of a radiograph, such as the x-ray device, the radiographed object, the x-ray geometry exposition, film and film processing. For didactic reasons, each factor is associated with its principal effect. In practice, however, all factors interact to determine the image quality. ${ }^{7}$

It is not always possible to test all those factors in simulation laboratory practical activities since it would be necessary many hours to complete the training and, also, because of the many different electrical configurations of dental x-ray devices. Additionally, it would be necessary several types of radiographic films, an appropriate mannequin, and sufficient available instructors to supervise the work performed by each one of the students.

Therefore, considering the challenges previously pointed and based on the assumption that learning is the process where the person develops behavior, knowledge, thinking, psychomotor abilities, professional ethical values, and also, assuming that teaching is a way to provide means to facilitate and support student learning, where the professor is responsible for creation of good opportunities to learn ${ }^{8}$; the present study aimed to develop and to evaluate a LO, where the student is able to use a computer to simulate different radiograph expositions, modifying the factors that interfere with the quality of the radiographic image.

\section{METHODOLOGY}

\section{Ethical Considerations}

This descriptive exploratory study, characterized as a research applied to technological production, was approved by the institutional Ethics Committee for Human Research (2007148H protocol).

\section{Learning Object Development}

To develop the LO - an informatics tool the following phases were performed: analysis, design, implementation and evaluation. ${ }^{9}$ These phases aimed to know if there was the necessity to implement the LO. In addition, the other objectives of LO developing phases were: to select appropriately the pedagogical and technological strategies, to describe the educational objectives, to produce and adapt digital materials, and to organize and design the environments. All these phases were necessary to further application in didactic situations and evaluations that should be made by students, in relation to the educational aspects and LO 
resources.

The elaboration of this LO is relevant since it is difficult for a dental student obtain good quality dental radiographic images, not only during the graduation $^{10-19}$, but also during their professional clinic activities $^{20,21}$; and because the identification of previous mistakes is fundamental to obtain a second successful radiograph. The educational objectives were defined based on this and on the epistemological constructivist approach, taking into consideration the cognitive, affective and psychomotor domains, as showed in figure 1.

\begin{tabular}{|c|c|c|}
\hline \multirow{4}{*}{ 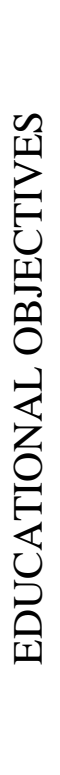 } & \multicolumn{2}{|r|}{ DOMAINS } \\
\hline & Cognitive & $\begin{array}{l}\text { To understand how the variations on the x-ray devices potency, on time of } \\
\text { exposition, on focal distance and on the film sensibility interfere in the x-ray } \\
\text { quality image. } \\
\text { To recognize which is the result of the simultaneous variation in two or } \\
\text { more than two of those factors. } \\
\text { To recognize what are the options to be used in the radiograph repetition }\left(2^{\text {nd }}\right. \\
\text { radiograph) to provide lower radiation exposition for the patient. }\end{array}$ \\
\hline & Affective & $\begin{array}{l}\text { To recognize the importance of the study proposal to obtain a reduction in } \\
\text { the radiograph repetitions. } \\
\text { To develop the way of work (work philosophy) based on radioprotection }\end{array}$ \\
\hline & Psychomotor & $\begin{array}{l}\text { To simulate the performing of radiographs of a same object, varying the } \mathrm{x} \text { - } \\
\text { ray device potency, the exposition time, the focal distance and the film } \\
\text { sensibility. } \\
\text { To be able to select the best factor that should be corrected aiming to obtain } \\
\text { good quality images. }\end{array}$ \\
\hline
\end{tabular}

Figure 1. Object learning educational objectives according to the different domains.

\section{Radiographic Images}

To obtain the radiographic images, a bone segment from the posterior region of a cadaveric dried bone human jaw with all posterior teeth was prepared. A $2 \mathrm{~cm}$ thickness plate of utility wax (Clássico Artigos Odontológicos, São Paulo, SP, Brazil) was used to simulate soft tissues. $^{3}$

All radiographies were obtained using a radiographic positioner device (Indusbello Indústria de Instrumentos Odontológicos Ltda, Londrina, PR, Brazil) to standardize the geometric factors. Images were obtained in two dental $\mathrm{x}$-ray devices with different $\mathrm{kV}$ and $\mathrm{mA}$ : 70X® (Gnatus, Ribeirão Preto, SP, Brazil) e Spectro X® (Dabi Atlante, Ribeirão Preto, SP, Brazil). Both were checked before the procedure, operating at $70 \mathrm{kVp} / 10 \mathrm{~mA}$ and $50 \mathrm{kVp} / 8 \mathrm{~mA}$, respectively. To register the images, different \#2 periapical films were used: Ektaspeed ${ }^{\circledR}(\mathrm{E}-$ Speed), Ultra-speed ${ }^{\circledR}(\mathrm{D}-$ Speed $)$, Insight ${ }^{\circledR}(\mathrm{E} / \mathrm{F}-$ Speed), all of them from the same commercial brand (Kodak® São Paulo, SP, Brazil). All films were processed at the same time by the timetemperature method, using new developer and fixing solutions (RPX-Omat ${ }^{\circledR}$, Kodak, São Paulo, SP, Brazil).

In each of one x-ray devices, $\mathrm{x}$-ray expositions were performed for each type of radiographic film, varying the focal distance $(20$ and $40 \mathrm{~cm})$ and the exposure time $(0,6,0,8,1,0 \mathrm{e}$ $1,5 \mathrm{~s})$. On total, 48 radiographs were obtained.

Each radiograph was digitized in a table scanner (Epson Perfection® 2450 - Epson, Long Beach, California, USA), under the use of a "black mask" that contained a hole with the same 
size of the film, aiming to avoid the passage of light outside the film limits. The parameters used for digitalization were 400dpi, 8 bits and real size. No tool for manipulate the images were applied in the digitized radiographs.

\section{Learning Object Construction}

Subsequently, it was planned the design of the LO. For that, the radiographic images were organized in an electronic spreadsheet, associating the images with each factor that had been used previously to obtain the image. For each one of the images, it was made a comment, with a value judgment regarding its quality, its applicability for the diagnosis, and, in case of necessity, suggestions or questions about the necessary adjustments.

In the LO home screen, the student was able to choose the focal distance $(20$ or $40 \mathrm{~cm}$ ) and the exposure time $(0,6 ; 0,8 ; 1,0$ ou $1,5 \mathrm{~s})$, as well as, to modify the $\mathrm{x}$-ray device (50 or $70 \mathrm{kVp}$ ) and the film speed (D, E or F) (figure 2a). Clicking on "simulate", the corresponding image arose, followed by the respective comment (figure $2 b$ ). These procedures aimed to stimulate the student to try various situations until obtaining the best result (figure $2 \mathrm{c}$ ).
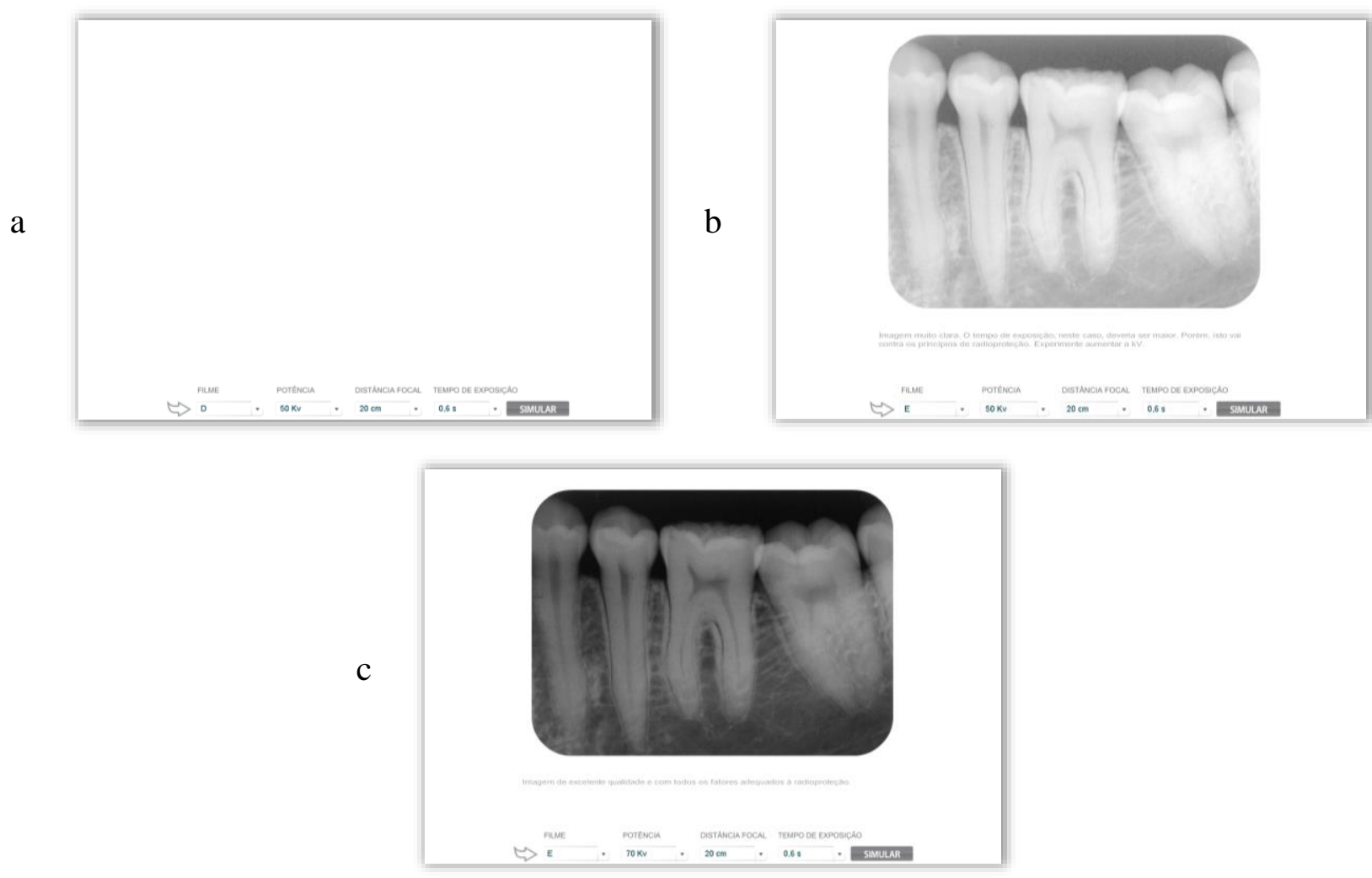

Figure 2. LO home screen (a); result of a non-satisfactory simulation with guidelines for its correction (b) and result of a successful simulation (c). 


\section{Learning Object Assessment}

All 64 enrolled students from the same class were divided, according their schedule availability, in two groups: class A and class B. These classes were again divided in two subgroups each: A1, A2, B1 and B2 (figure 3). During the first week (week-1) both classes participated in a theoretical lecture where the subject was "the radiographic factors that might interfere in the radiographic image'. The same professor delivered the lecture, and, subsequently, students answered a test/assessment (T1) on the subject.

In the following week (week-2) the students from Group 1 (Classes A1 and B2) solved practical exercises related to the subject, in the laboratory, in working groups of four students, and, at the end of the activity, all students answered a test/assessment (T2). Students from Group 2 (Classes A2 and B1) performed the activity with the LO in the laboratory, in working-groups of two students. At the end of the activity, they also answered the same second test/assessment, as well as, they answered an open-ended questionnaire to evaluate the activity.

At week-3 the same activities from the week before were repeated, reversing the classes, and, then, another test/assessment was applied (T3). After this class inversion, all students had access to all teaching-learning methods, to guarantee the ethical principles of beneficence.

Each test/assessment was composed of 10 multiple-choice questions: $\mathrm{T} 1$ provided a quantitative evaluation about the better use of information learnt in the theoretical class; $\mathrm{T} 2$ and T3 provided a quantitative evaluation about the better use of the subject learnt in the practical class, after they have performed the practical exercise and after working with the LO.

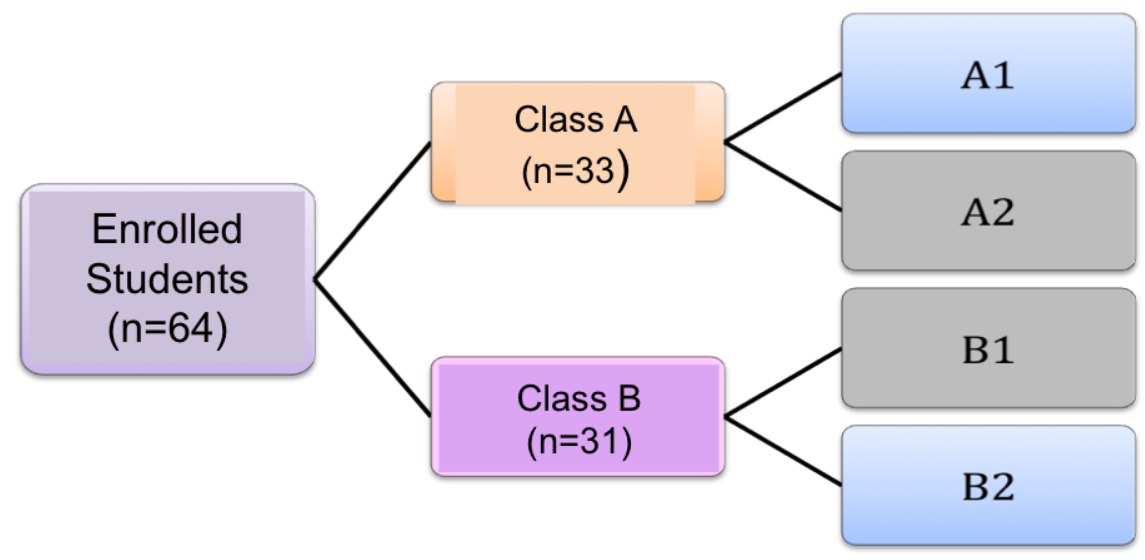

Group $1(\mathrm{n}=32)$

- Theoretical class (T1)

- Practical exercise (T2)

- Learning Object (T3)
Group $2(n=32)$

- Theoretical class (T1)

- Learning Object (T2)

- Practical exercise (T3)

Figure 3. Composition of groups (students' classes) and sequence of activities. 


\section{Statistical Tests}

The results from the students performance were compared using non-parametric Friedman test, where the variable was the percentage of correctness. Kolmogorov-Smirnov's test was used to compare the groups' performance in different moments of evaluation (T1, T2, and T3). In both comparisons, the significance level was set at $5 \%$.

The students' answers about the LO evaluation were descriptively presented. To process and to analyze these data the statistical analysis software SPSS was used (SPSS ${ }^{\circ}$ version 10.0 - IBM Analytics, Armonk, NY, USA).

\section{RESULTS}

From the 64 enrolled students, two of them did not accept to participate in the present research and four were absent at least once during the phases of the study, resulting in the sample of $\mathrm{n}=58$ students.

The percentage of correctness for the students groups at the three moments of evaluation is presented in table 1. According to Friedman test, for both groups, the performance in $\mathrm{T} 2$ was not statistically different from $\mathrm{T} 1$. However, T3 had higher results, statistically significant, than the two first tests/assessments. According to Kolmogorov-Smirnov test, there was not statistical difference in the groups' performance in any of the different moments of evaluation.

Questions 1 to 8 from the students' feedback (satisfaction questionnaire) regarding the LO use are presented in figure 4. All questions had more than $80 \%$ of approval. Questions 9 and 10 presented a broad range of answers that are summarized in figures 5 and 6 , respectively.

1- Which concept do you attribute to the LO?

2- In your opinion, do you think it was easy to access and to work with the LO?

3- was the comment that appeared on the radiograph image useful to your learning ?

4- Do you approve the LO layout?

5- Did the LO help you to solve doubts regarding the subject studied?

6- Did you like the subject approached in the LO ?

7- Was the language used in the LO adequate?

8- Do you think the availability of the LO anytime brings confidence to students?

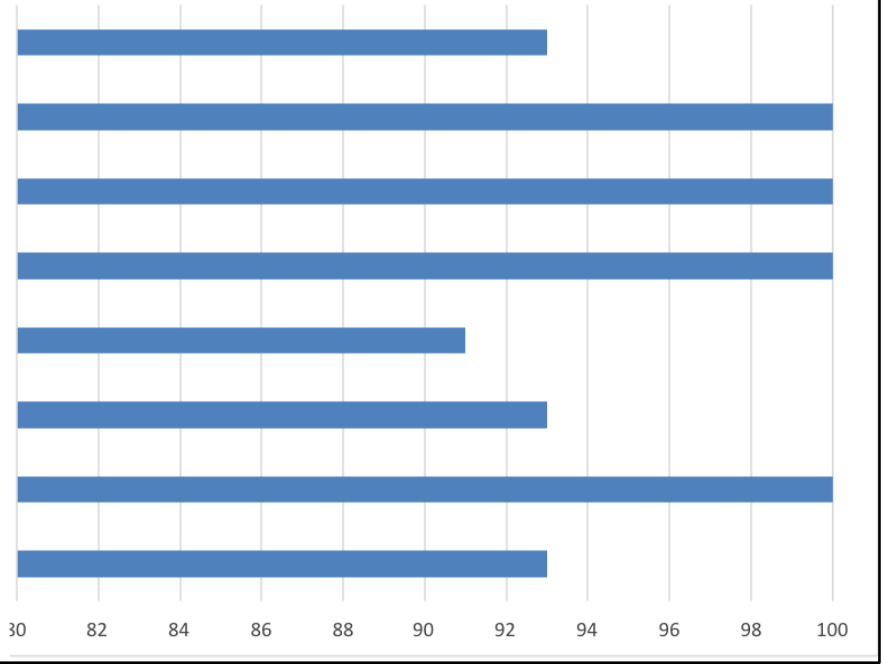

Figure 4. Acceptance levels for the LO in 8 from 10 characteristics addressed in the students' feedback (satisfaction questionnaire). 
Development and evaluation of a learning object focused on factors that might interfere on the radiographic image

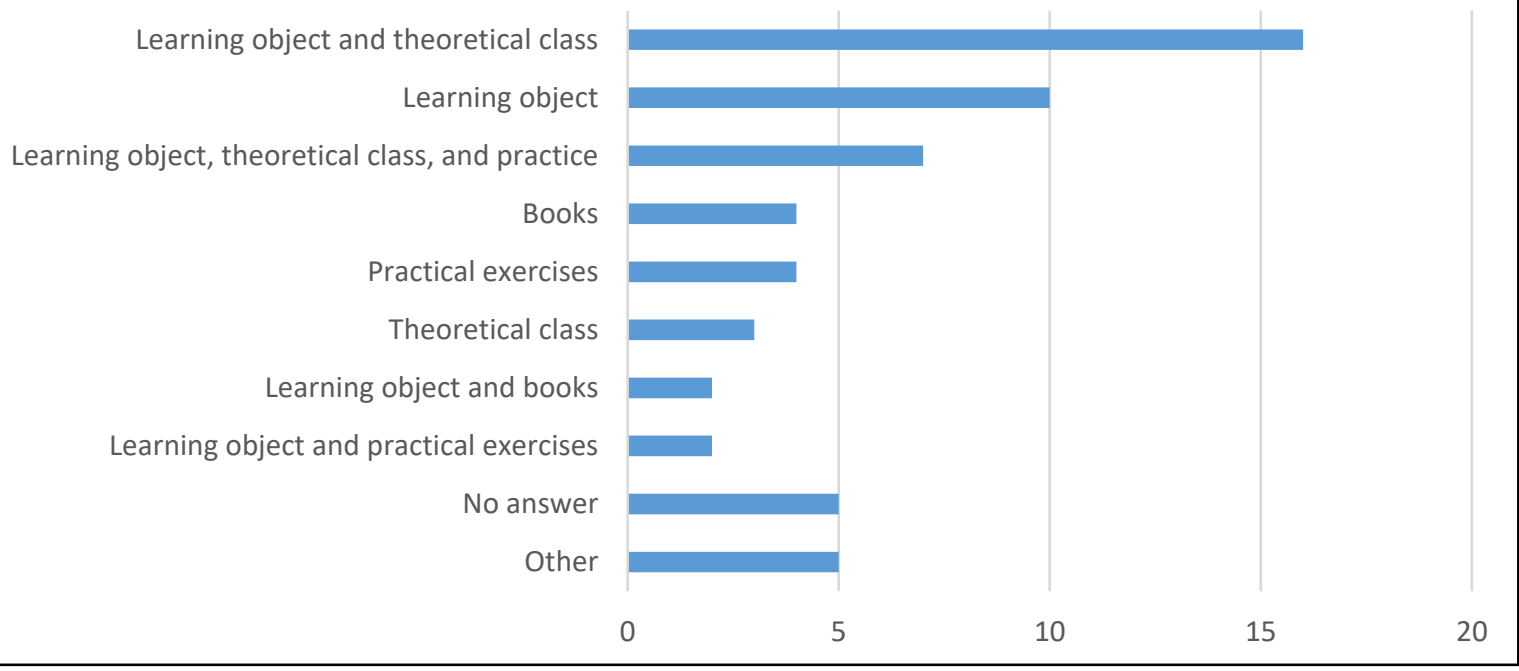

Figure 5 - Answers for question 9: "In your opinion, which is the best combination to study the addressed subject?" $(\mathrm{N}=58)$.

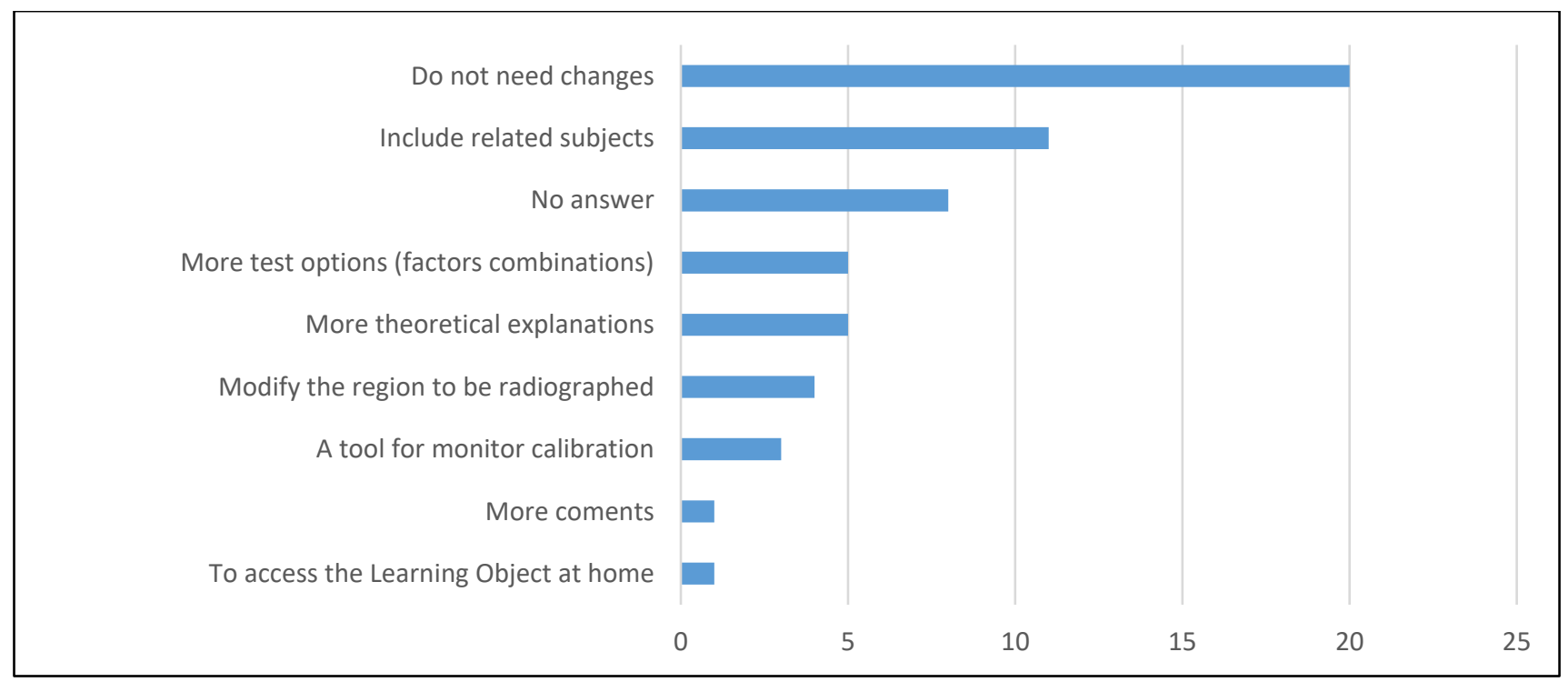

Figure 6. Answers for question 10: "What is your suggestion to make the Learning Object better?" $(\mathrm{N}=58)$.

Table 1. Comparison between the students` correctness obtained in T1 and T2, according the students' groups.

\begin{tabular}{lcccc}
\hline Comparison & Mean Percentage & Standard Deviation & Statistical test & P-value \\
\hline Group 1 & & & & \\
T1 & $27.10^{\mathrm{Aa}}$ & 21.01 & 25.83 & 0.000 \\
T2 & $28.00^{\mathrm{Aa}}$ & 21.40 & & \\
T3 & $59.31^{\mathrm{Ba}}$ & 22.35 & & \\
\hline Group 2 & & & & \\
T1 & $32.90^{\mathrm{Aa}}$ & 21.01 & & 0.000 \\
T2 & $26.45^{\mathrm{Aa}}$ & 21.53 & \\
T3 & $55.33^{\mathrm{Ba}}$ & 21.45 & & \\
\hline
\end{tabular}




\section{DISCUSSION}

The use of the LO did not improve significantly the frequency of students' correctness (number of correct responses) in the tests/assessments. However, the LO methodology was considered very good, because, according to the participants, it was a tool that stimulates learning. Indeed, students had a better performance in the third assessment, which might be occurred due to the more time spent to study the subject.

Several students suggested that the LO should be applied to other radiology subjects, with emphasis in radiographic technique and anatomy. This positive result regarding the students' opinions is in accordance with the majority of studies found in the literature, in which the technological apps are considered positive. Even though, these apps do not quantitatively improve the formal tests/assessments. ${ }^{24-32}$ In this regard, few studies have found significant results. ${ }^{33-35}$ It is important to bear in mind that statistical results, sometimes, might not be reflect exactly what occurs in the clinical practice. Therefore, it is essential to suggest and implement new learning tools in Dentistry, such as, contemporary technologies as digital educational games.

The LO simulates the clinical practice, reinforcing what is the best combination of factors to do radiographic images. The aim of the LO is to encourage students to obtain a good image quality combined with a low radiation exposition for the patient. A higher frequency of correctness (higher number of correct responses) could be reached if the test had addressed more practical questions, and students had had time to study before taking the theoretical assessment. Instead of being able to remember and to repeat the information, the student should be able to find the information and use it.

It is important to have a realistic view about the amount of time that is needed to learn complex subjects. Long-term evaluation would make possible a better investigation about the efficacy of the simultaneous learning, traditional learning associated to digital resources, to help students to reach an optimal performance. Only one professor delivered the theoretical class and supervised students, in the informatics laboratory, but the supervision of students in the radiology laboratory (when they worked in the practical activities) was made by a group of professors.

In the informal conversation at the informatics laboratory, after using the LO, the students were confident to choose a combination of factors aiming to take a good radiography. All participants were able to use the computer, using it easily and interacting with the LO language. The students' familiarity with informatics tends to improve over time, due to the wide implementation of computers/informatics in people's daily-life and in schools since the first years of education. Therefore, the ability of people in using computers is no longer an obstacle to the implementation of interactive programs and on-line activities/courses in the teaching-learning process. It is just the opposite as to what happened in the end of the twentieth century, when the students' abilities to use computers varied at random. ${ }^{36}$

Walmsley et al. ${ }^{37}$ observed that dentistry professors are concerned about the students' trend to reduce searching research in the literature as a result of the availability of easy-to read knowledge on the internet. Our findings showed that around $10 \%$ of participants thought that the best way to learn is to associate the use of LO with the literature. Nowadays, the access to the online information is fast, easy and noncostly to the users. Such a fact is very good to the contemporary students, since, often, the universities libraries provide very few books 
copies that are updated, because they are costly to be purchased. Besides that, the speed of new information and knowledge is so fast that books might become dated in a short period. Thus, the search for information online should be classified as a complement and effective manner to build knowledge. The student only need to be prepared to filter the useful information and to develop his/her critical thinking.

This type of study tool (as research websites, libraries online, and also the LO) are subsidiary to the traditional search of information (books, journals, study polygraphs etc.), bringing benefits for students, such as, comfort and safety (they can search at home) and, the possibility to revise subjects if they forgot or they did not comprehend. $^{38}$

In conclusion, the Learning Object did not contribute to the quantitative improvement of tests/assessments, but it was widely approved by the students. The use of the LO, in addition to the practical exercises, contributed to the learning process on the factors that might interfere on the radiographic image.

\section{RESUMO}

\section{Desenvolvimento e avaliação de um objeto de aprendizagem sobre fatores que interferem na imagem radiográfica}

Considerando as dificuldades apresentadas pelos estudantes de odontologia na obtenção de imagens radiográficas de qualidade, o presente estudo teve por objetivos desenvolver e avaliar um objeto de aprendizagem (OA) no qual o usuário possa simular exposições radiográficas, modificando os fatores que interferem na qualidade da imagem radiográfica. Para este estudo exploratório descritivo, 48 radiografias periapicais foram obtidas da região posterior de uma mandíbula humana seca, com diferentes combinações de $\mathrm{kVp} / \mathrm{mA}$, sensibilidade do filme, distância focal e tempo de exposição. A cada imagem foi atribuído um texto sobre sua qualidade, aplicabilidade ao diagnóstico e, se necessário, sugestões ou questões sobre ajustes requeridos. Na tela do OA os estudantes podem simular situações combinando os diferentes fatores até que obtenham o melhor resultado. Para a avaliação do OA, 64 alunos de graduação foram divididos em dois grupos. Todos os alunos participaram da aula teórica e realizaram um teste. Na semana seguinte o Grupo 1 executou exercícios práticos e o Grupo 2 utilizou o OA, ambos respondendo a um segundo teste. $\mathrm{Na}$ terceira semana os grupos inverteram as atividades e foi aplicado o terceiro teste. Um questionário aberto foi respondido por todos os alunos com intuito de avaliar qualitativamente o OA. Não houve diferença estatisticamente significante quanto aos acertos nos testes entre os grupos. O OA não melhorou o desempenho dos estudantes em testes, porém foi considerado como uma metodologia muito boa, que estimula o aprendizado. A utilização do OA somou-se aos exercícios práticos, melhorando no aprendizado dos fatores que podem interferir na imagem radiográfica.

Descritores: Educação Odontológica. Tecnologias de Informação e Comunicação. Objeto de Aprendizagem. Radiologia Odontológica.

\section{REFERENCES}

1. Schardosim M, Lara MC, Fontanella VR. Tecnologias de informação e comunicação no ensino da odontologia. Rev ABENO. 2007;7:67-81.

2. Wiley DA. Connecting learning objects to instructional design theory: a definition a metaphor, and a taxonomy. 2001. [Acesso em 15 mai. 2016]. Disponível em: http://reusability.org/read/chapters/wiley.doc.

3. Gama CLG. Scheer S. Avaliação de objetos educacionais para Educação a Distância de engenharia: construção, reuso e avaliação. In: Congresso Internacional de educação à distância,12, 2005, Florianópolis - SC. Programação do $12^{\circ}$ CIED. Florianópolis : ABED e UFSC, 2005. v.1. p.1-8. [Acesso em 15 fev. 2016] Disponível em: http://www.abed.org.br/congresso2005/por/ pdf/159tcc3.pdf.

4. Macedo LN, Macedo AAM, Filho JAC. Avaliação de um Objeto de Aprendizagem 
com base nas teorias cognitivas. Workshop sobre informática na escola. Anais do WIE 2007. Rio de Janeiro, 2007, p. 330-8.

5. Flores MLP, Santos LMA, Bandeira NA, Falkembach GAM, Reis FV. O uso de teorias cognitivas na construção de Objetos de Aprendizagem para suporte ao ensino de Matemática. In: IADIS International Conference, 2006, Murcia. p. 328-32.

6. Tarouco LMR, Cunha SLS. Aplicação de teorias cognitivas ao projeto de Objetos de Aprendizagem. Novas Tecnologias CINTED-UFRGS na Educação. Porto Alegre - RS, 4(2):1-9, 2006. [Acesso em 02 jun. 2016]. Disponível em: http://www. cinted.ufrgs.br/renote/dez2006/artigosrenot e/25025.pdf.

7. Whaites E. Princípios de Radiologia Odontológica. $4^{\mathrm{a}}$ ed. Rio de Janeiro: Elsevier, 2009.

8. Nilson EF, Walmsley D, Brennan $\mathrm{M}$, Fournier DM, Glass BJ, Haden K, et al. Cognition and learning. Eur J Dent Educ. 2002;6(Suppl. 3):27-32.

9. Filatro AC. Design instrucional contextualizado: educação e tecnologia. São Paulo: Editora SENAC; 2004.

10. Ribas ME, Souza BC, Fontanella VRC. Avaliação da qualidade de radiografias intrabucais realizadas por acadêmicos da FO-UFRGS. Rev ABENO. 2008;8(1):4950.

11. Kreich EM, Queiroz MGS, Sloniak MC. Controle de qualidade em radiografias periapicais obtidas no curso de Odontologia da UEPG. Publ UEPG Ci Biol Saúde. 2002; 8(1):33-45.

12. Fernandes AMM, Aguiar APS, Cruz LP, Aivazoglou MU, Gomes APM, Silva EG, et al. Avaliação dos erros radiográficos cometidos por alunos de graduação durante o tratamento endodôntico. Rev Odontol Univ Cid São Paulo. 2010;22(3):216-22.

13. Matheus RA, Montebel Filho A, Tanaka EE, Barros RMP. Avaliação no desempenho de acadêmicos durante tomadas radiográficas periapicais, pela técnica da bissetriz, realizadas na Faculdade de Odontologia da
Universidade Norte do Paraná (Unopar). RFO UPF. 2000;5(2):25-9.

14. Queiroga MAS, Moreno NPP, Figueiredo CBO, Abreu MHNG, Brasileiro CB. Avaliação dos erros radiográficos cometidos por graduandos de odontologia em técnicas radiográficas intrabucais. Arq Odontol. 2010;46(3):61-5.

15. Carvalho PL, Neves ACC, Zollner NA, Rosa LCL, Almeida ETDC. Erros técnicos nas radiografias intrabucais realizadas por alunos de graduação. RGO. 2009;57(2):1515.

16. Pontual MLA, Veloso HHP, Pontual AA, Silveira MMF. Errores en radiografias intrabucales realizadas en la Facultad de Odontología de Pernambuco-Brasil. Acta Odontol Venez. 2005; 43(1):19-24.

17. Mendonça DM, Amorim MEB, Medina PO, Filho AOA, Brito TCCA, Conde NCO. Avaliação de erros em exames radiográficos intrabucais realizada por acadêmicos de Odontologia/UFAM. Rev Odontol Univ Cid São Paulo. 2014;26(2):119-26.

18. Gonçalves A, Bóscolo FN, Gonçalves M. Análise de erros radiográficos cometidos por alunos de Faculdade de Odontologia durante o tratamento endodôntico. RFO UPF. 2003; 8(1):61-5.

19. 19 Silva JM, Oliveira LC, Daroz BG, Peyneau PD, Pereira TCR, de-Azevedo-Vaz SL. Erros cometidos por estudantes de Odontologia de uma universidade pública brasileira na realização de radiografias periapicais. Rev ABENO. 2016;16(1):99109.

20. 20 Helminen SE, Vehkalahti M, Wolf J, Murtomaa H. Quality evaluation of young adults' radiographs in Finnish public oral health service. J Dent. 2000;28(8):549-55.

21. Ferreira LPF, Santos CE. A qualidade da radiografia e erros mais comuns na auditoria radiográfica. Braz J Forensic Sci Med Law Bioethics. 2015;4(3):288- 93

22. Rushton VE, Hirshmann PN, Bearn DR. The effectiveness of undergraduate teaching of the identification of radiographic film faults. Dentomaxillofac Radiol., 2005;34,337-42. 
23. Braga CPA, Gegler A, Fontanella V. Avaliação da influência da espessura e da posição relativa de materiais simuladores de tecidos moles na densidade óptica de radiografias periapicais da região posterior da mandíbula. Ciênc Odontol Bras. 2006; 9(4):52-8.

24. Wenzel A, Gotfredsen E. Students attitudes toward and use of computer assisted learning in oral radiology over a 10-year period. Dentomaxillofac Radiol. 1997;26:132-6.

25. Aly M, Elen J, Willems G. Instructional multimedia program versus standard lecture: a comparison of two methods for the undergraduate orthodontic curriculum. Eur J Dent Educ. 2004;8(1):43-6.

26. Botelho M. The use of Group participation and an enquiry-based study guide with computer assisted learning. Eur J Dent Educ. 2001;5:109-12.

27. Halsted MJ, Perry LA, Perry DJ, Benton C. Development of na interactve model for teaching emergency pediatric radiography preliminary report. J Am Call Radiol. 2005;2(8):701-3.

28. Imber S, Shapira G, Gordon M, Judes H, Metzger Z. A virtual reality dental simulator predicts performance in an operative dentistry manequin course. Eur J Dent Educ. 2003;7:160-3.

29. Al-Rawi WT, Jacobs R, Hassan BA, Sanderink G, Scarfe WC. Evaluation of web-based instruction for anatomical interpretation in maxillofacial cone bean computed tomography. Dentomaxillofacial Radiology. 2007;36:459-67.

30. Howerton WB, Enrique PR, Ludlow JB, Tyndal DA. Interactive computerassisted instruction vs. Lecture format in dental education. J Dent Hyg. 2004;78(4): 10.

31. Quinn F, Keogh P, Mconald A, Hussey D. A pilot study comparing the effectiveness of conventional training and virtual reality simulation in the skills acquisition of junior dental students. Eur J Dent Educ. 2003;7:139.

32. Howerton WB, Platin E, Ludlow J, Tyndal DA. The influence of computer assisted instruction on acquiring early skills in intrabucal radiography. $\mathrm{J}$ Dent Educ. 2002;66(10):1154-8.

33. Ávila MAG. Software anatomia em radiografias panorâmicas: avaliação do método de ensino-aprendizado em Odontologia. [Tese] São Paulo (SP): Universidade de São Paulo; 2004. 174p.

34. Bogacki RE, Best A, Abbey LM. Equivalence study of a dental anatomy computer assisted learning program. J Dent Educ. 2004;68(8):867-71.

35. Stiller EM, Jost-Brinkmann PG, Miethke RR. The Integration of a computer learning program for X-Ray cefalometrics analisis into student training. Fortschritte der Kieferorthopädie. 1993;54(3):129-33.

36. Mattheos N, Nattestad A, Schittek M, Attström R. Computer literacy and attitudes among students in 16 European dental school: current aspects, regional differences and future trends. Eur $\mathbf{J}$ Dent Educ. 2002;6:30-5.

37. Walmsley AD, White DA, Eynon R, Somerfield $\mathrm{L}$. The use of the internet within a dental school. Eur J Dent Educ. 2003;7:2733.

38. Eynon R, Perryer G, Walmsley AD. Dental undergraduate expectations and opinions of web-based courseware to supplement traditional teaching methods. Eur J Dent Educ. 2003;7:103-10.

Correspondência para:

Vania Regina Camargo Fontanella

e-mail: vaniafontanella@terra.com.br

Faculdade de Odontologia da UFRGS

Rua Ramiro Barcelos, 2492

90035-003 Porto Alegre/RS 